\title{
The effects of phytosterol in low fat milk on serum lipid levels among mild- moderately hypercholesterolemic subjects
}

\author{
Sri Sukmaniah ${ }^{1}$, Saptawati Bardosono ${ }^{1}$, Samuel Oetoro ${ }^{1}$, Inge Permadhi ${ }^{1}$, Leilani Lestarina ${ }^{2}$
}

\begin{abstract}
Abstrak
Salah satu risiko terpenting dari penyakit jantung koroner adalah dislipidemia, antara lain hiperkolesterolemia atau tingginya kadar kolesterol-LDL darah. Fitosterol merupakan salah satu komponen makanan yang diketahui dapat menurunkan kolesterol darah, sehingga merupakan komponen dalam terapi diet untuk perbaikan pola hidup. Penelitian ini bertujuan untuk mempelajari efek fitosterol yang dilarutkan dalam susu rendah lemak pada subyek dengan hiperkolesterolemia ringan-sedang. Telah dilakukan uji klinik terbuka dengan 2 kelompok sejajar di Departemen Ilmu Gizi FKUI bulan Juni - Nopember 2006. Masing-masing subyek dialokasikan secara acak untuk menerima konseling khusus dan susu yang mengandung 1,2 g fitosterol/hari (kelompok perlakuan) atau hanya menerima konseling khusus saja (kelompok kontrol) selama periode 6 minggu. Tidak ada perubahan kadar kolesterol total dan kolesterol-LDL serum yang bermakna pada kelompok kontrol setelah pengamatan selama 6 minggu (berturut-turut 218,3 $\pm 18,6$ mg/dL menjadi 219,6 $\pm 24,3 \mathrm{mg} / \mathrm{dL}$ dan $164,7 \pm 21 ., 8 \mathrm{mg} / \mathrm{dL}$ menjadi $160,0 \pm 26,4 \mathrm{mg} / \mathrm{dL})$. Sebaliknya, terdapat penurunan kadar kolestero total dan kolesterol-LDL yang bermakna pada kelompok perlakuan ( $p=0,01$ dan $p=0,004)$ setelah pengamatan selama 6 minggu (berturut-turut 233,5 $\pm 24,6 \mathrm{mg} / \mathrm{dL}$ menjadi $211,2 \pm 30,3 \mathrm{mg} / \mathrm{dL}$ dan $176,9 \pm 23.9 \mathrm{mg} / \mathrm{dL}$ menjadi $153.8 \pm 23.7 \mathrm{mg} / \mathrm{dL}$ ). Jumlah penurunan $\mathrm{kadar}$ kolesterol-LDL serum sebelum dan sesudah perlakuan pada kelompok perlakuan $(22.4 \pm 27,9 \mathrm{mg} / \mathrm{dL})$ lebih besar secara bermakna $(p=0,024)$ dibanding dengan kelompok kontrol $(4,7 \pm 17,2 \mathrm{mg} / \mathrm{dL})$. Tidak ada perubahan bermakna pada kadar kolesterol-HDL dan trigliserida serum pada kedua kelompok. Walaupun tidak ada perbedaan bermakna dalam asupan zat gizi dari makanan, namun pada kelompok perlakuan didapatkan penurunan bermakna pada berat badan $(p=0,000)$, indeks massa tubuh $(p=0,000)$ dan lingkar perut (0,000). Disimpulkan bahwa penurunan kadar kolesterol total dan kolesterol-LDL pada kelompok subyek yang menerima konseling khusus dan susu yang mengandung fitosterol 1,2 g/hari selama 6 minggu secara bermakna lebih besar dibanding dengan kelompok subyek yang menerima konseling khusus saja. (Med J Indones 2008; 17: 5-12)
\end{abstract}

\begin{abstract}
One of the most important risk factors for CHD is dyslipidemia, among others hypercholesterolemia or high LDL-cholesterol. Plantsterols or phytosterols (PS) are among dietary factors known to lower blood cholesterol as part of therapeutic life-style changes diet. This study was aimed to evaluate the effect of PS properly solubilized in a-partly vegetable oil-filled low fat milk, on serum lipid levels in mild-moderate hypercholesterolemic subjects. Randomized, two-arm parallel control group trial was conducted at Department of Nutrition-University of Indonesia in Jakarta from June to November 2006. Each subject was randomly assigned to receive dietary lifestyle changes counseling plus $1.2 \mathrm{~g}$ phytosterol/day in low-fat milk (PS-group) or control group receiving the counseling alone for six weeks period. There were no significant changes of serum total and LDL-cholesterol of control group after a six week of dietary counseling (respectively $218.3 \pm 18.6 \mathrm{mg} / \mathrm{dL}$ to $219.6 \pm 24.3 \mathrm{mg} / \mathrm{dL}$ and $164.7 \pm 21.8 \mathrm{mg} / \mathrm{dL}$ to $160.0 \pm 26.4 \mathrm{mg} / \mathrm{dL}$ ). There were a significant decreases of serum total and LDL-cholesterol (respectively $p=0.01$ and $p=0.004$ ) among subjects receiving PS after a six weeks observation period (respectively $233.5 \pm 24.6 \mathrm{mg} / \mathrm{dL}$ to $211.2 \pm 30.3 \mathrm{mg} / \mathrm{dL}$ and $176.9 \pm 24.7 \mathrm{mg} / \mathrm{dL}$ to $154.5 \pm 24.3 \mathrm{mg} / \mathrm{dL}$ ). There was a significant difference in the LDL-lowering effects $(p=0.024)$ among the PS-group after a six weeks $(22.4 \pm 27.9 \mathrm{mg} / \mathrm{dL})$ as compared to the control group $(4.7 \pm 17.2 \mathrm{mg} / \mathrm{dL})$. No significant changes were found on serum HDL-cholesterol and triglyceride levels in both groups. Although there was no significant difference found in daily nutrients intake between the-2 groups, however, significant reductions in body weight, body mass index and waist circumference were found only in the PS group ( $p=0.000$; 0.000; 0.003, respectively). It is concluded that the lowering of total and LDL-cholesterol in those receiving life-style changes counseling plus $1.2 \mathrm{~g}$ PS daily for six weeks was significantly higher as compared to those of receiving counseling alone. (Med J Indones 2008; 17: 5-12)
\end{abstract}

Keywords: TLC Diet, LDL-cholesterol, HDL-cholesterol, triglyceride, phytosterol, body mass index, waist-circumference

\footnotetext{
${ }^{1}$ Nutrition Department Faculty of Medicine, University of Indonesia, Jakarta, Indonesia

${ }^{2}$ PT Nestle Indonesia, Jakarta, Indonesia
}

Cardiovascular disease (CVD) has been the leading cause of death, among which coronary heart disease (CHD) is the most prevalent. Based on epidemiologic 
studies, there are several risk factors identified for the development of CHD. One of the most important is dyslipidemia, especially hypercholesterolemia, and hypertriglyceridemia. ${ }^{1.2 .3}$

In Indonesia, based on data from Ministry of Health (2004) the prevalence of hypercholesterolemia was 9.3\% among those aged of 25-34 years and increasing up to $15.5 \%$ among those aged 55-64 years old. Along with the increasing incidence of $\mathrm{CHD}$ among productive age group, many studies have been done for its prevention and treatment using food-based as well as pharmacologicbased approaches. ${ }^{4}$ Many clinical trials have been carried out to find the dietary components which have cholesterol-lowering effect. Plant sterol -also known as phyto-sterols- are among the dietary factors known to lower blood cholesterol. In recent years, the effects of phytosterol on the concentration of serum lipid profile, fat-soluble vitamins, and carotenoids have been studied intensively.

The National Cholesterol Education Program Adult Treatment Panel III (NCEP-ATP III, 2001) and the American Heart Association (AHA) have recommended the use of functional food or foods high in components that reduce cholesterol as additional options to enhance the effectiveness of cholesterol-lowering diets. ${ }^{5,6}$

Dietary advice is the initial treatment recommended for moderate hypercholesterolemia, and lipid lowering drugs should be restricted to subjects at highest overall risk of coronary heart disease who do not respond to dietary modification. ${ }^{7}$

Phytosterol (PS) or sterol isolated from plants has a cholesterol-like structure. It has been esterified and encorporated in food source such as low fat milk, yoghurt, and margarines. Consuming phytosterol between 2 to $3 \mathrm{~g}$ per day lowers serum total and LDLcholesterol by $9 \%$ to $20 \%$ without affecting HDLcholesterol. ${ }^{8}$ There are two mechanisms proposed for cholesterol-lowering effect of phytosterol, first, by inhibiting absorption of dietary cholesterol in which plant sterols displace cholesterol of the micelles in the intestinal lumen and hence inhibiting absorption of both endogen and exogen cholesterol. The second, by triggering the oxysterol activity, a ligand of nuclear receptor i.e. LXR, a heterodimer of another nuclear receptor,. RXR that regulates genes involved in lipid absorption, excretion, and metabolism. ${ }^{9,10,11}$

This study aims to evaluate the effect of $1.2 \mathrm{~g} / \mathrm{day}$ phytosterol fortified in low fat milk and dietary counseling on serum lipid levels in mild-moderately hypercholesterolemia subjects, compared to dietary counseling alone.

\section{METHODS}

This study used an open, randomized, two-arm parallel pre-post test design, which was conducted at Department of Nutrition-University of Indonesia in Jakarta from June to November 2006. Each subject was randomly assigned to one of the following interventions, each for a period of six week, i.e., Phytosterol (PS) group (Counseling plus $1.2 \mathrm{~g}$ phytosterol daily in low-fat milk), and Control (C) group (Counseling alone).

Test products (low fat milk containing phytosterol) were provided by PT Nestle Indonesia with the nutritional facts as shown in appendix 1.

Population and subjects were volunteers with known mild-moderate hypercholesterolemia who responded to the study invitation and who fulfilled the criteria for the study.

\section{Inclusion criteria}

1) Body mass Index $>18.5 \mathrm{~kg} / \mathrm{m}^{2}$

2) Female or male volunteers aged 25-55 years old.

3) Serum cholesterol between $200-299 \mathrm{mg} / \mathrm{dl}$

4) No medical history of metabolic diseases (Renal failure, Diabetes mellitus, Nephrotic syndrome or hypothyroidism)

\section{Exclusion criteria}

1) Ingesting cholesterol lowering effect drugs, or

2) Drugs known to interfere with lipid profiles (hormone replacement treatment, diuretics, and $\beta$-blockers)

3) Pregnant or Nursing mother

Sample size was calculated for the minimal sample size using the following formula:

$$
\mathrm{n}_{1}=\mathrm{n}_{2}=\frac{2\{(\mathrm{Z} \alpha+\mathrm{Z} \beta) * \mathrm{~s}\}^{2}}{\mathrm{~d}^{2}}
$$

Using standard deviation of difference in LDL cholesterol before intervention of phytosterol of $0.29 \mathrm{mmol} / \mathrm{L}$ and the mean of difference $0.34 \mathrm{mmol} / \mathrm{L}$, the minimal sample size needed for each group was $16 .{ }^{13}$

Serum total cholesterol was measured in subjects visiting the Department of Nutrition Clinic. Eligible 
subjects were randomized consecutively to one of the two different interventions (week 0). Beforehand, the subjects were informed about the study protocol and signed the informed consent.

The subsequent visits were scheduled at each two week: week $1,3,5$, and week 7 . Altogether, each patient underwent 5 visits, including the screening session.

At each visit during the intervention period, subjects were asked about the study tolerance, specifically the occurrence of nausea, abdominal cramps, vomiting, diarrhea and flatulence. The serum total-, LDL-, HDL-cholesterol and triglyceride was determined at week 1 (baseline) and week-7 (end-line). In addition, systolic and diastolic blood pressures were measured using sphygmomanometer after the subject had rested for at least 15 minutes. Subject's weight and height were measured at the first visit, and the weight was measured subsequently at each visit. The body weight was measured using secca alpha scale with the accuracy of $0.1 \mathrm{~kg}$ and the height using microtoise statue meter with the accuracy $0.1 \mathrm{~cm}$. The body mass index was calculated as: $\mathrm{BMI}=$ weight $/(\text { height })^{2} \mathrm{~kg} / \mathrm{m}^{2}$.

To assess subject's compliance, any left over study product was returned and weighed at the two-weekly visit intervention period (week 3, 5, and 7). A new study product was dispensed for each two week period, separately.

During the study, nutritional counseling was given by nutritionists for behavior change. It was designed for a daily low fat and low cholesterol diet (less than 30\% energy contribution from fat, and less than $200 \mathrm{mg} /$ day cholesterol), high intake of fruits and vegetables, and active lifestyle for each subject. Compliance was evaluated every two week visit whereas failure to comply with the diet and lifestyle restriction was valued as 0 .

Data were presented as mean \pm standard deviation. Comparisons were made using the mean of anthropometric, nutrient intake, and total, LDL-, HDL-cholesterol, and triglyceride values of the two measurements taken before and after the intervention period.

Normal distribution was checked using the KolmogorovSmirnov test, before doing the parametric and nonparametric statistical analysis. Prior to further analysis, homogeneity of variance was performed.

For hypothesis testing, the study used paired and unpaired t-test if the data were normally distributed (otherwise the suitable non-parametric tests was used).
P-values of less than 0.05 were considered statistically significant.

All participants gave written informed consent, and the study had received approval from the Ethical Committee of Faculty of Medicine-University of Indonesia.

\section{RESULTS}

This study has recruited 40 eligible subjects. Random allocation was done to get 20 subjects for each of phytosterol and control group. However, three from the PS and six from the $\mathrm{C}$ groups lost to follow up giving the drop out rate of 15 to $30 \%$. By this condition, the study power $(\beta)$ was still in the adequate range of 80 to $90 \%$. The number of subjects included for final data analysis fulfilled the minimal sample size of the study $(n=16)$ for PS group but not for the $\mathrm{C}$ group.

The characteristics of the subjects in the two groups of intervention during the screening phase are presented in table 1 for the demographic and anthropometric characteristics and in table 3 for the blood pressure, biochemical, and nutrient intake characteristics.

Table 1. Demographic and anthropometric characteristics of the subjects based on group of intervention at screening-phase

\begin{tabular}{|c|c|c|}
\hline & $\begin{array}{l}\text { Phytosterol } \\
\text { group }\end{array}$ & $\begin{array}{c}\text { Control } \\
\text { group }\end{array}$ \\
\hline $\mathrm{n}$ & 17 & 14 \\
\hline Age, $y$ & $40.4 \pm 7.5$ & $43.1 \pm 8.4$ \\
\hline \multicolumn{3}{|l|}{ Sex: } \\
\hline Male & 9 & 2 \\
\hline Female & 8 & 12 \\
\hline \multicolumn{3}{|l|}{ Education level: } \\
\hline Less than high school & 3 & 3 \\
\hline High school & 6 & 1 \\
\hline College/university & 8 & 10 \\
\hline \multicolumn{3}{|l|}{ Working status: } \\
\hline Not working & 5 & 6 \\
\hline Employee & 9 & 6 \\
\hline Business & 3 & 2 \\
\hline \multicolumn{3}{|l|}{ Anthropometric status: } \\
\hline Weight, $k g$ & $68.5 \pm 8.1$ & $66.3 \pm 7.6$ \\
\hline Height, $m$ & $157.1 \pm 6.8$ & $159.2 \pm 7.2$ \\
\hline BMI, $k g / m^{2}$ & $27.8 \pm 4.1$ & $26.3 \pm 3.5$ \\
\hline Waist-circumference, $\mathrm{cm}$ & $90.6 \pm 5.8$ & $86.1 \pm 8.5$ \\
\hline
\end{tabular}

Values are means $\pm \mathrm{sd}$ 
Table 2. Blood-pressure, biochemical, and nutrient intake characteristics of the subjects based on group of intervention at screening-phase

\begin{tabular}{lccc}
\hline & $\begin{array}{c}\text { Phytosterol } \\
\text { group }\end{array}$ & $\begin{array}{c}\text { Control } \\
\text { group }\end{array}$ & p-value \\
\hline $\mathrm{n}$ & 17 & 14 & \\
Blood-pressure, $m m H g:$ & & & \\
$\quad$ Systolic & $122.1 \pm 13.7$ & $119.6 \pm 14.2$ & \\
$\quad$ Diastolic & $81.2 \pm 7.6$ & $79.3 \pm 8.3$ & \\
Biochemical status: & & & \\
$\quad$ Total cholesterol, $m g / d L$ & $236.1 \pm 23.4$ & $225.8 \pm 15.8$ & 0.171 \\
$\quad$ Creatinine, $m g / d L$ & $0.8 \pm 0.2$ & $0.7 \pm 0.1$ & \\
$\quad$ Alkali phosphatase, $U / L$ & $71.8 \pm 14.5$ & $73.7 \pm 15.4$ & \\
Nutrient intake status: & & & \\
$\quad$ Calorie intake, $k c a l$ & $2272.6 \pm 734.7$ & $1845.6 \pm 912.2$ & 0.159 \\
$\quad$ Protein, $g$ & $74.4 \pm 27.2$ & $65.0 \pm 43.8$ & 0.473 \\
Carbohydrate, $g$ & $274.7 \pm 107.9$ & $239.4 \pm 109.4$ & 0.374 \\
Fats, $g$ & $90.2 \pm 37.9$ & $76.2 \pm 41.6$ & 0.336 \\
$\quad$ Cholesterol, $m g$ & $257.5 \pm 170.7$ & $289.8 \pm 332.7$ & 0.729 \\
Carotene, $m g$ & $9.0 \pm 10.8$ & $7.2 \pm 7.2$ & 0.591 \\
Fiber, $g$ & $17.5 \pm 10.4$ & $13.2 \pm 7.8$ & 0.208 \\
\hline
\end{tabular}

Values are means $\pm \mathrm{sd}$

Table 3. Clinical, anthropometric, and physical activity index characteristics of the subjects before and after the intervention based on the intervention group

\begin{tabular}{|c|c|c|}
\hline & $\begin{array}{l}\text { Phytosterol } \\
\text { group }\end{array}$ & $\begin{array}{l}\text { Control } \\
\text { group }\end{array}$ \\
\hline $\mathrm{n}$ & 17 & 14 \\
\hline \multicolumn{3}{|l|}{ Blood-pressure, $\mathrm{mmHg}$ : } \\
\hline Systolic $^{1}, m m H g$ & $127.4 \pm 13.5$ & $113.9 \pm 15.9$ \\
\hline Systolic $^{2}, m m H g$ & $122.6 \pm 14.6$ & $118.2 \pm 9.5$ \\
\hline$p$-value ${ }^{* *}$ & $N S$ & $N S$ \\
\hline Diastolic $^{1}, m m H g$ & $85.0 \pm 7.5$ & $77.9 \pm 11.7$ \\
\hline Diastolic $^{2}, m m H g$ & $81.2 \pm 9.3$ & $77.1 \pm 6.1$ \\
\hline$p$-value $* *$ & $N S$ & $N S$ \\
\hline \multicolumn{3}{|l|}{ Anthropometric status: } \\
\hline Height, $m$ & $157.1 \pm 6.8$ & $159.2 \pm 7.4$ \\
\hline Weight ${ }^{1}, k g$ & $68.2 \pm 7.9$ & $65.6 \pm 7.7$ \\
\hline Weight $^{2}, k g$ & $65.8 \pm 7.7$ & $64.3 \pm 9.5$ \\
\hline$p$-value* & 0.000 & $N S$ \\
\hline $\mathrm{BMI}^{1}, k g / m^{2}$ & $27.8 \pm 3.9$ & $26.0 \pm 3.9$ \\
\hline $\mathrm{BMI}^{2}, k g / m^{2}$ & $26.8 \pm 4.0$ & $25.4 \pm 3.9$ \\
\hline p-value* & 0.000 & $N S$ \\
\hline Waist-circumference $^{1}, \mathrm{~cm}$ & $89.0 \pm 6.0$ & $85.4 \pm 7.5$ \\
\hline Waist-circumference $^{2}, \mathrm{~cm}$ & $85.2 \pm 5.7$ & $84.1 \pm 6.0$ \\
\hline$p$-value $*$ & 0.003 & $N S$ \\
\hline Physical activity index ${ }^{1}$ & $6.9 \pm 1.1$ & $6.2 \pm 1.7$ \\
\hline Physical activity index ${ }^{2}$ & $7.2 \pm 1.3$ & $7.7 \pm 1.4$ \\
\hline$p$-value* & $N S$ & 0.008 \\
\hline
\end{tabular}

Values are means \pm sd

NS: no significant difference $(\mathrm{p}>0.05)$
As expected, there were no significant differences on the demographic, anthropometric, blood-pressure, biochemical, and nutrient intake characteristics of the subjects based on group of intervention at the screening-phase Table 3).

Table 4. Nutrient-intakes of the subjects before and after the intervention based on the intervention group

\begin{tabular}{|c|c|c|}
\hline & $\begin{array}{l}\text { Phytosterol } \\
\text { group }\end{array}$ & $\begin{array}{c}\text { Control } \\
\text { group }\end{array}$ \\
\hline $\mathrm{n}$ & 17 & 14 \\
\hline \multicolumn{3}{|l|}{ Nutrient intake status: } \\
\hline Calorie $^{1}$, kcal & $1185.1 \pm 308.7$ & $1122.8 \pm 290.2$ \\
\hline Calorie $^{2}$, kcal & $1199.8 \pm 234.6$ & $1104.4 \pm 319.6$ \\
\hline p-value* & $N S$ & $N S$ \\
\hline Protein $^{1}, g$ & $37.2 \pm 9.8$ & $35.9 \pm 10.1$ \\
\hline Protein $^{2}, g$ & $34.7 \pm 9.6$ & $42.9 \pm 15.6$ \\
\hline$p$-value* & $N S$ & $N S$ \\
\hline Carbohydrate $^{1}, g$ & $168.4 \pm 54.1$ & $144.4 \pm 34.0$ \\
\hline Carbohydrate $^{2}, g$ & $152.6 \pm 34.2$ & $141.9 \pm 38.8$ \\
\hline p-value* & $N S$ & $N S$ \\
\hline Fats $^{1}, g$ & $31.8 \pm 13.9$ & $36.5 \pm 21.8$ \\
\hline Fats $^{2}, g$ & $28.3 \pm 12.8$ & $34.2 \pm 20.5$ \\
\hline$p$-value* & $N S$ & $N S$ \\
\hline Cholesterol $^{1}, m g$ & $99.4 \pm 105.6$ & $120.8 \pm 93.7$ \\
\hline Cholesterol $^{2}, m g$ & $72.0 \pm 59.0$ & $104.4 \pm 75.6$ \\
\hline$p$-value* & $N S$ & $N S$ \\
\hline Fiber $^{1}, g$ & $9.4 \pm 4.0$ & $8.1 \pm 3.3$ \\
\hline Fiber $^{2}, g$ & $8.4 \pm 2.3$ & $6.9 \pm 1.8$ \\
\hline$p$-value* & $N S$ & $N S$ \\
\hline
\end{tabular}

${ }^{1}$, before intervention; ${ }^{2}, 6$ weeks after the intervention

*) using unpaired t-test, or Mann-Whitney

NS, no significant difference ( $p$ value $>0.05$ )

The effect of the six week intervention on the clinical, anthropometric, physical activity index nutrient intakes and biochemical, characteristics as well as the differences in serum lipid levels before and after the intervention are shown in Table 3, 4, and 5.

Statistically, there were no significant changes on systolic and diastolic blood pressure in either group between before and after the intervention. Anthropometrically, significant reductions in weight, body mass index and waist circumference were found in PS group between before and after intervention but not for the $\mathrm{C}$ group. A significant increase in the physical activity index was only found in $\mathrm{C}$ group.

No significant nutrient intake changes were found in the two groups before and after the intervention 
For the serum total- and LDL-cholesterol concentrations, significant reductions were found in the PS group, while no significant reductions of serum HDLcholesterol and triglyceride. In the $\mathrm{C}$ group, there were no significant changes of serum lipid concentrations. It showed that the significant reduction of total- and LDL cholesterol levels in PS group were due to the intervention of phytosterol. However, the weight in this group was also reduced which might contribute to the reduction of total- and LDL-cholesterol.

The lowering effect on serum total cholesterol, and LDL-cholesterol in PS group was significantly greater than that of the $\mathrm{C}$ group (Table 5).

Table 5. Serum lipid levels of the subjects before and after the intervention based on the intervention group

\begin{tabular}{|c|c|c|c|}
\hline & Phytosterol group & Control group & p-value** \\
\hline $\mathrm{n}$ & 17 & 14 & \\
\hline Total cholesterol ${ }^{1}, m g / d L$ & $233.5 \pm 24.6$ & $218.3 \pm 18.6$ & \\
\hline Total cholesterol ${ }^{2}, m g / d L$ & $211.2 \pm 30.3$ & $219.6 \pm 24.3$ & \\
\hline$p$-value* & 0.01 & $N S$ & \\
\hline \multirow[t]{2}{*}{ Difference in serum total cholesterol, $m g / d L$} & $-22.3 \pm 28.7$ & $1.3 \pm 18.8$ & 0.009 \\
\hline & $(-9.2 \pm 12.3 \%)$ & $(0.7 \pm 9.0 \%)$ & 0.013 \\
\hline LDL-cholesterol $^{1}, m g / d L$ & $176.9 \pm 24.7$ & $164.7 \pm 21.8$ & \\
\hline LDL-cholesterol $^{2}, m g / d L$ & $154.5 \pm 24.3$ & $160.0 \pm 26.4$ & \\
\hline$p$-value* & $P=0.004$ & $N S$ & \\
\hline \multirow[t]{2}{*}{ Difference in serum LDL-cholesterol, $m g / d L$} & $-22.4 \pm 27.9$ & $-4.7 \pm 17.2$ & 0.024 \\
\hline & $(-11.5 \pm 16.7 \%)$ & $(-2.8 \pm 10.5 \%)$ & $N S$ \\
\hline HDL-cholesterol ${ }^{1}, m g / d L$ & $43.6 \pm 8.0$ & $46.8 \pm 9.0$ & \\
\hline HDL-cholesterol $^{2}, m g / d L$ & $40.3 \pm 8.0$ & $45.9 \pm 3.7$ & \\
\hline$p$-value* & $N S$ & $N S$ & \\
\hline \multirow[t]{2}{*}{ Difference in serum HDL-cholesterol, $m g / d L$} & $-3.2 \pm 6.5$ & $-0.9 \pm 6.8$ & $N S$ \\
\hline & $(-6.7 \pm 13.2 \%)$ & $(0.5 \pm 14.7 \%)$ & $N S$ \\
\hline Ratio LDL/HDL-cholesterol ${ }^{1}$ & $4.2 \pm 0.9$ & $3.7 \pm 1.0$ & \\
\hline Ratio LDL/HDL-cholesterol $^{2}$ & $4.0 \pm 1.1$ & $3.5 \pm 0.6$ & \\
\hline$p$-value* & $N S$ & NS & \\
\hline \multirow[t]{2}{*}{ Difference in LDL-HDL ratio } & $0.18 \pm 0.96$ & $0.18 \pm 0.61$ & $N S$ \\
\hline & $(3.2 \pm 26.6 \%)$ & $(1.7 \pm 16.4 \%)$ & $N S$ \\
\hline Triglyceride $^{1}, m g / d L$ & $167.6 \pm 65.4$ & $109.6 \pm 32.9$ & \\
\hline Triglyceride $^{2}, m g / d L$ & $146.8 \pm 56.9$ & $118.8 \pm 40.0$ & \\
\hline$p$-value* & $N S$ & $N S$ & \\
\hline \multirow[t]{2}{*}{ Difference in serum triglyceride, $m g / d L$} & $-20.8 \pm 57.7$ & $9.1 \pm 41.1$ & $N S$ \\
\hline & $(-6.7 \pm 31.0 \%)$ & $(14.1 \pm 41.7 \%)$ & NS \\
\hline
\end{tabular}

${ }^{1}$, before intervention; ${ }^{2}, 6$ weeks after the intervention

*) using paired t-test, or Wilcoxon;

**) using unpaired t-test, or Mann-Whitney

$\mathrm{NS}$, no significant difference ( $\mathrm{p}$ value $>0.05$ ) 


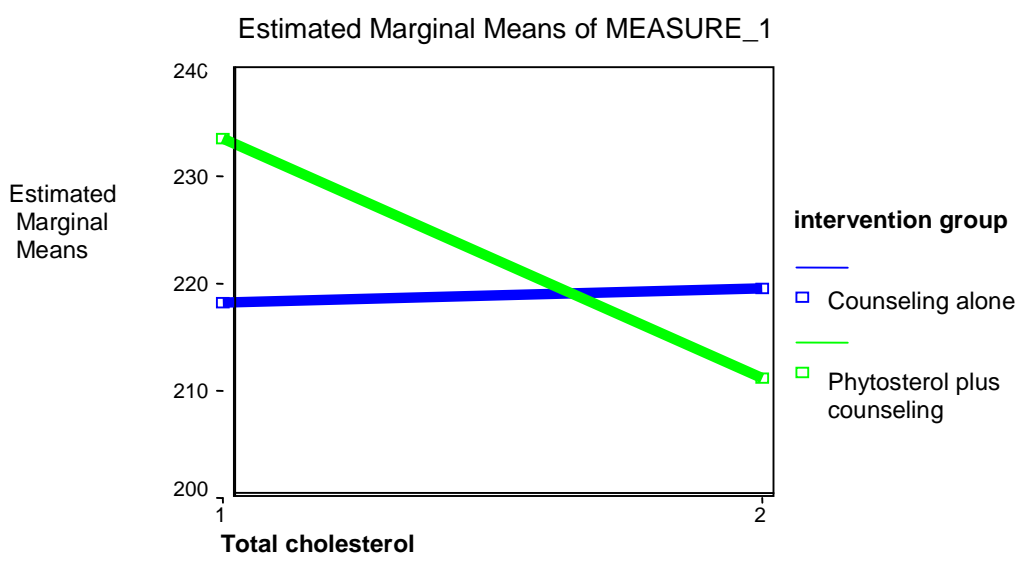

Figure 1. The changes of serum total cholesterol before and after the six weeks intervention among the two groups

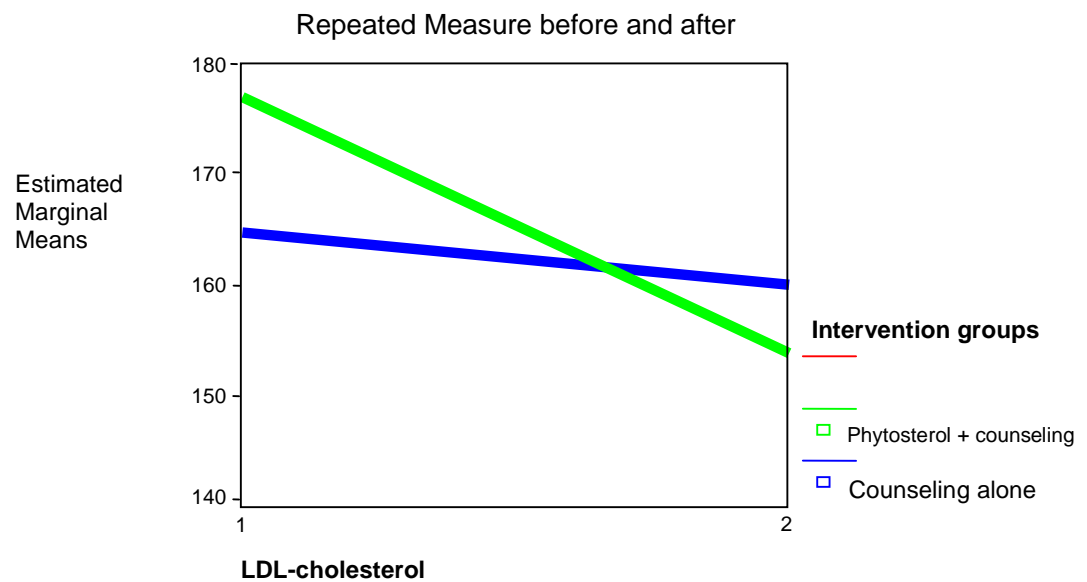

Figure 2. The changes of serum LDL-cholesterol before and after the six weeks intervention among the intervention groups

Estimated Marginal Means of MEASURE_1

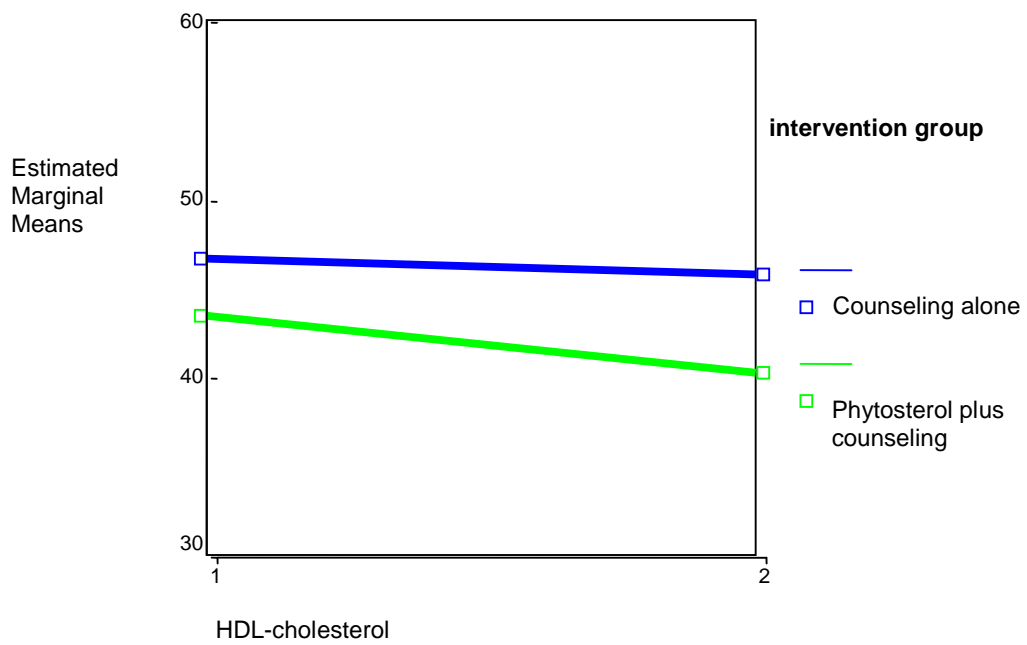

Figure 3. The changes of serum HDL-l cholesterol before and after the six weeks intervention among the two groups 


\section{DISCUSSIONS}

The number of subjects who completed the study was 17 for Phytosterol (PS) group and 14 for control (C) group. This sample size is still within adequate range. The base-line data collected at screening phase (table 2 and 3) showed the homogeneity of age and anthropometric status in both groups and no significant differences in dietary intakes between the two groups.

After six weeks intervention of low-fat milk fortified by $1.2 \mathrm{~g}$ phytosterol/day plus life style changes counseling (PS group) as well as counseling alone (C group) there were no effects on blood pressure, as expected (table 3). The weight, BMI, and waist circumference in PS group decreased significantly, while in $\mathrm{C}$ group the reduction was not significant. This is inline with other studies that showed dietary advice contribute to less than $5 \%$ of reduction in total cholesterol. $^{16}$

In PS group, there was significant reduction of weight, BMI, and waist circumference even though there was no significant reduction of energy intake. It was still unclear for the underlying mechanism of these anthropometric changes in this group.

The significant increase in physical activity index in the $\mathrm{C}$ group, which might be due to the additional effect of dietary counseling, might indicate their effect on the decreasing of anthropometric measures in this group, although its decreasing was not significant (Table 4). As a whole, the changes of dietary intakes were not significant; however the dietary intake changes might be suggested to contribute partly for changes of their anthropometric measures.

The total- and LDL-cholesterol were decreased significantly after a six weeks intervention in the PS group by $9.2 \pm 12.3 \%$ and $11.5 \pm 16.7 \%$ respectively, while serum HDL-cholesterol and triglyceride did not decrease significantly. In $\mathrm{C}$ group there were no significant changes for all serum lipid measures. The results of PS group were supported by Mensink et al, 2002 who found that supplementation of $3 \mathrm{~g} / \mathrm{day}$ phytostanols ester in low-fat yoghurt for 4 weeks, reduced LDL-cholesterol by $14 \%$ without significant changes on plasma HDL-cholesterol and triglyceride levels. ${ }^{13}$ Several studies showed that daily consumption of 0.7- $3.2 \mathrm{~g}$ plant sterol per day had shown to reduce total cholesterol by 5.0-13.0 \% and LDL cholesterol by $5.6-24.4 \%$ in both normo- and hypercholesterolemic persons with and without diabetes. ${ }^{17}$ While lipid lowering diet with highly motivated subjects can result in a 3-4\% reduction in total cholesterol concentration. ${ }^{16}$

The decreased in serum total- and LDL- cholesterol levels in the PS group is consistent with other studies which reported that the supplementation of phytosterolfortified food products (1-4 g/day) may reduce circulated cholesterol levels by $8-15 \%$ within 3 to 6 weeks in mildly hypercholesterolemic subjects. One of the mechanisms in reducing serum LDL-cholesterol was suggested to be the inhibition of its absorption and the increment of its efflux from enterocytes into the intestine lumen. ${ }^{10,11,18}$

The reduction effect on serum HDL level in PS group of the present study, although not significant, might be due to the up regulation of gene expression of cholesterol ester transfer protein (CETP) which transfer the cholesterol ester from HDL to LDL molecules.' Even-though the dosage of phytosterol in this present study was lower than the Mensink study, but the period of this present study was longer which might be expected to influence the reduction of the HDL level. ${ }^{13}$

The dietary life style changes counseling seemed to have no effect on dietary intake and serum LDLcholesterol profile, however, a six weeks dietary counseling alone was able to increase physical activity index significantly as one of the recommended lifestyle changes. The study by Jones et al, 1999, supported the present study which showed that after 30 days administration of $1.7 \mathrm{~g}$ phytosterol mixture-enriched diet daily, there were significant reductions of serum total cholesterol $(\mathrm{p}<0.05)$ and of LDL-cholesterol by $24.4 \%(\mathrm{p}<0.001)$ compared to control $(8.9 \%, \mathrm{p}<0.01)$, without significantly changing the concentrations of HDL-cholesterol and triglyceride. ${ }^{4}$ The other studies of the effects of phytosterol on serum cholesterol concentration also supported the present study, which showed that there was significant reduction of serum LDL-cholesterol after three weeks intervention of $1.6 \mathrm{~g} /$ day phytosterol-enriched low-fat milk. ${ }^{2,14}$ The study by Clifton et al (2004) showed the dose-related lowering effect of plant sterols on serum LDL levels, which found the reduction of serum LDL levels by $7.13 \pm 12.31 \%$ for Low (sterol intake $1.2 \mathrm{~g} / \mathrm{day}$ ), and $9.59 \pm 12.44 \%$ for High (sterol intake $1.6 \mathrm{~g} /$ day) groups $(\mathrm{p}<0.0001) .{ }^{14}$ Clifton et al, also showed that the matrix of food product influence its cholesterollowering effect, and the phytosterol-containing milk was the most effective food product in reducing the concentration of cholesterol compared with yoghurt, bread, and cereal. 


\section{CONCLUSIONS}

Dietary counseling alone for 6 weeks do not have impact on the reductions of total- and LDL-cholesterol, while the provision of $1.2 \mathrm{~g}$ phytosterol daily in lowfat milk for six weeks is able to decrease the total cholesterol by $9.2 \%$ (or equal to $22.3 \mathrm{mg} / \mathrm{dL}$ ) and LDL-Cholesterol by $11.5 \%$ (or equal to $22.4 \mathrm{mg} / \mathrm{dl}$ ).

\section{REFERENCES}

1. Krummel DA. Nutrition in cardiovascular disease. In: Mahan LK, Escott-Stump S, eds. Krause's Food, Nutrition and diet therapy. $11^{\text {th }}$ ed. Philadelphia: Saunders; 2000. 35.p: 860-99.

2. Thomsen $\mathrm{AB}$, Hansen $\mathrm{HB}$, Christiansen $\mathrm{C}$, Green $\mathrm{H}$, Berger A. Effect of free plants sterol in low-fat milk on serum lipid profile in hypercholesterolemic subjects. Eur J Clin Nutr. 2004;58.860-70.

3. Tribble DL, Krauss RM. Atherosclerotic cardiovascular disease, In: Bowman BA \& Russell eds. Present knowledge in nutrition. ILSI Press, Washington, DC. $8^{\text {th }}$ ed, 2001; p.543-51.

4. Jones PJH, Ntanios FY, Sarjas MR, Vanstone CA. Cholesterol lowering efficacy of a sitostanol-containing phytosterol mixture with diet in hyperlipidemic men. Am J Clin Nutr. 1999;69:1144-50

5. Expert Panel on Detection, Evaluation and Treatment of High Blood Cholesterol in Adults. Executive summary of the third report of the National Cholesterol Education Program (NCEP) Expert Panel on Detection, Evaluation and Treatment of High Blood Cholesterol in Adults. Adult Panel Treatment III. JAMA. 2001:285:2486-97.

6. Krauss RM, Eckel RH, Howard B, et.al. AHA dietary guidelines revision 2000: a statement for healthcare professionals from Nutrition Committee of the American Heart Association. Circulation. 2000;102:2284-99

7. Ockene IS, Hebert JR, Ockene JK, Spaeria GM, Stanek E, Nicolosi R. Merriam PA, Hurley TG. Effect of physiciandelivered nutrition counseling training and an officesupport program on saturated fat intake, weight and serum lipid measurements in hyperlipidemic population: Worchester Area Trial for Counselling in Hyperlipidemia (WATCH). Arch Intern Med. 1999;159:725-31
8. Hallikainen MA, Sarkkinen ES, Gylling H, Erkkilä AT, Uusitupa MIJ. Comparison of the effect of plant sterol ester and plant stanol ester-enriched margarines in lowering serum cholesterol concentrations in hypercholesterolaemic subject on a low fat. Eur J Clin Nutr. 2000. 54:715-25.

9. Edward PA, Kast HR, Anisfelt AM. BAREing it all: adoption of LXR and FXR and their roles in lipid homeostasis. J Lipid Res. 43:2-12

10. Trautwein EA, Duchateau GSMJE. Phytosterol sources and metabolism. In: Awad AB and Bradford PG. eds. Nutrtion and cancer prevention. CRC, Taylor and Francis group, New York, 2006. p: 223-41

11. Turley SD, Dietchy JM. Sterol absorption in small intestine. Curr Op Lipiodol. 2003;14: 233-40

12. Korpela R, Tuomilehto J. Hőgstrőm P, Seppo L, Piironen V, Salo-Väänänen P, Tivo J, Lamberg-Allard C, Kärkäinen M, Outila T, Sundvall J, Vikkilä S, Tikkanen MJ. Safety aspects and cholesterol-lowering efficacy of low fat dairy products containing plant sterols. Eur J Clin Nutr. 2006; 60:633-42

13. Mensink RP. Ebbing S. Lindhout M, Plat J, Heugten MMA. Effects of plant stanol esters suplied in low-fat yoghurt on serum lipids and lipoprotein, non-cholesterol sterol and fat soluble antioksidant concentrations. Departement of Human Biology, Maastricht University. www.elsevier.com. 2002.p. 205-13

14. Clifton PM, Noakes M, Sullivan D, Erichsen N, Ross D, Annison G, Fassoulakis A, Cehun M, and Nestel P. Cholesterol-lowering effects of plant sterol esters differ in milk, yoghurt, bread, and cereal. Eur J Clin Nutr. 2004; 58:503-8

15. Vanstone CA, Raeini-Sarjaz M, Parsons WE, Jones PJH. Unsterified plant sterols and stanols lower LDL-cholesterol concentrations equivalently in hypercholesterolemic persons. Am J Clin Nutr. 2002;76:1272-8

16. Burr ML, Fehily AM, Gilbert JF, Rogers S, Holliday RM, Sweetnam PM, et.al. Effects of changes in fish, fat and fiber intakes on death, and myocardial infarction: a fiet and reinfarction trial (DART). Lancet. 1989;ii: 757-61

17. Gyling H. Miettinen TA. Serum cholesterol and cholesterol and lipoprotein metabolism in hypercholesterolemic NIDDM subjects before and during sitostanol-ester margarine treatment. Diabetologia. 1994; 37:773-80

18. Brousseau ME. ATP-binding cassette transporter A 1, fatty acids, and cholesterol absorption. Current Opinion in Lipidology. 2003;14:35-40 